\title{
Study of some cooking and eating quality characters on some Egyptian rice genotypes
}

\author{
${ }^{1}$ N. B. Nessreen $-{ }^{2}$ A. K. Ammar $-{ }^{3,4}$ A. Ezzat \\ ${ }^{1}$ Rice Research and Training Center (RRTC), Agricultural Research Center, Egypt \\ ${ }^{2}$ Food Science and Technology Department, Faculty of Agriculture, University of Kafr El-Shiekh, Kafr El-Shiekh \\ ${ }^{3}$ University of Debrecen Faculty of Agricultural and Food Sciences and Environmental Management, Institute of Horticulture, Debrecen \\ ${ }^{4}$ Horticulture Department, Faculty of Agriculture, University of Kafr El-Shiekh, Kafr El-Shiekh
}

\begin{abstract}
SUMMARY
Some Egyptian rice genotypes [i.e. Japonica (Sakha 104), Japonica/Indica (Egyptian hybrid1) and Indica (Giza 182)] were investigated to evaluate the cooking and eating quality characters. High significant differences in grain shape were observed among rice genotypes. Hulling, milling and head rice percentage were higher in Sakha 104 than other rice genotypes, while Indica type (Giza 182) recorded the lowest values in milling and physical characters. No significant differences were found in chemical composition of the three genotypes of rice was recorded, but Giza 182 had the highest protein content. All Egyptian rice genotypes were low in gelatinization temperature and soft in gel consistency. Japonica and Indica rice varieties were low in amylase content, while Japonica/Indica rice variety was intermediate. The use of RVA is considered a good index for palatability evaluation for milled rice flour and starch. The Indica and Japonica/Indica types are low in breakdown viscosity, but higher in cooked pasta than Japonica type. Japonica type recorded the best score in panel test, followed by Indica type, while Indica/Japonica rice variety was the least accepted by Egyptian consumer.
\end{abstract}

Keywords: rice, genotype, protein content, breakdown viscosity

\section{ÖSSZEFOGLALAS}

Vizsgálataink célja az volt, hogy megállapitsuk bizonyos egyiptomi rizs genotípusok [Japonica (Sakha 104), Japonica/Indica (Egyiptomi hibrid) és Indica (Giza 182)] fözési és étkezésminöségi tulajdonságait. Szignifikáns különbség volt a rizs genotípusok között a szem alakjában. A hántolás, örlés és az egész rizsszemek arányát tekintve a Sakha 104 jobban teljesített a többi rizs genotipusnál, míg az Indica (Giza 182) esetében mértük a legalacsonyabb értékeket az örlés és a fizikai tulajdonságok kapcsán. Nem volt szignifikáns különbség a három rizs genotípus beltartalmi tulajdonságai között, de a Giza 182 fajta rendelkezett a legmagasabb fehérjetartalommal. Az összes egyiptomi rizs genotípusnak alacsony volt a zselatinizálódási hömérséklete, a gél konzisztenciájuk pedig lágy volt. A Japonica és Indica fajták amiláztartalma alacsony volt, a Japonica/Indica rizsfajtaé pedig közepes. Az RVA (gyors viszkoanalizátoros technika) használata általában jó indikátor az örölt rizsliszt és keményitö izletességére vonatkozóan. Az Indica és a Japonica/Indica fajták viszkozitás-csökkenése alacsony, ugyanakkor a fött tésztában magasabb, mint a Japonica fajta esetében. A panel teszt során a Japonica fajta érte el a legjobb eredményt, a második legjobb fajta pedig az Indica volt. Az Indica/Japonica volt a legkevésbé elfogadottabb fajta az egyiptomi fogyasztók körében.

Kulcsszavak: rizs, genotipus, fehérjetartalom, viszkozitás-csökkenés

\section{INTRODUCTION}

Cereal grains and legumes are the main source of dietary energy as well as a source of proteins and vitamins. For example, rice is widely consumed as a staple food in world (Byun et al., 2010). Rice is typically consumed as cooked rice, although a small amount is used as an ingredient in processed foods. Grain shape, a typical complex quantitative trait, is closely associated with grain weight and usually measured by grain length, width, thickness and length-to-width ratio (Yoon et al., 2006). Length-to-width is considered an important measure of rice appearance quality since people's preferences are rather different in the rice-producing areas of the world (Wang et al., 2008). 1000-grain weight is an important agronomic trait of rice. Grain weight not only has close correlations with grain number per panicle and yield but also affects apparent and processing qualities of grains, such as percentage of chalky grain, brown rice, milled rice, and head rice ( $\mathrm{Li}$ et al. 2008). Brown rice is a rice kernel dehulled from rough rice and consists of embryo (2-3\%), endosperm (92\%), and bran (5-6\%). Milling yield, is milled rice after milling processing "Head rice recovery", is defined as the percentage of whole milled rice kernel obtained from rough rice (paddy rice) after milling. Milling yield is an economically important trait of commercial rice because the price of rice for whole grains is typically twice that of broken grains (Childs, 2006). Each milling component may be affected by multiple traits (sub-components) such as kernel dimension, kernel hardness, and bran thickness, as well as other factors. Many of the subcomponent traits of milling yield are under the control of numerous genes, and therefore milling yield and its sub-components are quantitatively inherited. Breeding for improved milling yield is, therefore, difficult because the trait exhibits complex inheritance. Amylose content was considered one of the most important characteristics for cooking behavior. For instance, cooked rice with low amylose content was generally soft and sticky, while rice with high amylose content was relatively firm and fluffy (Rani and Bhattacharya, 1989). The texture of cooked rice is related to its amylose content and the fine structure of amylopectin. The intra and/or inter-molecular interactions of starch with other components in rice such as proteins, lipids and nonstarch polysaccharides affect rice's texture (Prasert and Suwannaporn, 2009). Gelatinization, retrogradation and pasting properties of rice starch and flour, as well as the texture of cooked rice, are related to the fine structure 
of amylopectin (Bhattacharya, 2009). A number of researchers have reported that protein increases pasting viscosity of rice flour, and they hypothesised that some proteins in rice gran protect starch granules from breaking down (Xie, et al., 2008). Pasting properties, color, flavor, and composition affect rice cooking and eating quality (Teo et al., 2000) and depend on rice variety and amylose content. Such changes have been attributed to changes in cell walls and proteins, interaction between proteins and the breakdown products of lipid oxidation, and starch protein interaction (Sodhi et al., 2003). Champagne et al. (1999) demonstrated that many cultivars with similar amylose contents showed rather different pasting and textural properties. The differences in amylograph viscosity between flour and starch of rice (Singh et al., 2000) indicated that other components than amylose also affected the cooking properties of rice. Protein is the second most abundant component of rice grain after starch, and so should be investigated for its potential effects on eating and cooking quality. Recently, the Brabender Visco Amylograph and the Rapid Visco Analyser (RVA) were used to study the effect of protein on the pasting properties of rice flour. Viscosity decreased along all the points of the curve, when rice flour was treated with a protease. The addition of DTT to rice cooking water increased stickiness and decreased the hardness of almost all cooked rice (Derycke et al., 2005). The particle size distribution of rice flour is known to play an important role in its functional properties and the quality of end products. Some unique functional properties of rice make it a desirable grain to be used in value-added products. Rice flour has soft taste, colorless, hypoallergenic properties, low levels of sodium and easy digestible carbohydrates. Because of these properties, rice flour is the most suitable cereal to make gluten free products (Lopez et al., 2004). The object of this study are to evaluate the physical, chemical, cooking and eating quality of some Egyptian rice genotypes characters.

\section{MATERIAL AND METHODS}

Fresh harvested grains of $14 \%$ moisture content of three rice genotypes i.e Sakha 104 (Japonica type), Egyptian hybrid 1 (Indica/Japonica) and Giza 182 (Indica type) produced from planting at $5^{\text {th }}$ May during summer seasons 2012 were used to investigate the grain quality and chemical compositions of milled rice Characters. About 150 grams (three replication) of rough rice for all samples were taken, mixed and cleaned. Grain shape and physical characters were determine as described by Khush et al. (1979). Milling recovery characters i.e. Hulling, milling and head rice percentage were estimated according to the methods reported by Adair (1952). Flour was analyzed for the following chemical composition moisture content, protein content (N X 5.95), lipids content, ash content, crude fibbers content and total carbohydrate content according to the method described by A.O.A.C. (1990). Cooking and eating quality characters i.e. gelatinization temperature, amylose content and gel consistency test were estimated for milled rice samples following the methods of Little et al. (1958). Juliano (1971) and Cagampang et al. (1973) respectively. Rapid Viso Analyzer (RVA) was used to investigate the amylogrsphic gelatinization viscosity characteristic for the three Egyptian milled rice flour genotypes following the method reported by El-Kady (1999). Milled rice samples (1 kg) were cooked and were served to a panel of 10 Judges for evaluation. The judges were instructed to sip water before and after tasting each sample. The samples were evaluated before cooking for three rice varieties. Water ratios, grain length, shape and translucency, after cooking they evaluated for cooking time, kernel expansion, whiteness, odor, stickiness and taste according to Peryam and Shapiro (1955). The samples were evaluated using ten points scale for each character with maximum scores of 80 and a limit of acceptability of 60 scores. Treatments means were compared by Duncan's multiple range test (Duncan, 1955).

\section{RESULTS AND DISCUSSION}

Data in Table 1 show the characters of three rice genotypes in terms of grain length, width and shape. Grain length was highly significant affected for the three rice varieties. Giza182 had the tallest grain length (6.62) but there was no significant difference between Egyptian hybrid1 and Sakha 104. This may be due to its parents. While the shortest was Sakha $104(5.50 \mathrm{~mm})$. The lowest in Grain Width was Giza1 82 (1.86 mm), but there was no significant difference between Egyptian hybrid 1 rice and Sakha 104 in grain width. Grain shape expressed as the ratio between grain length and width. Data in Table 1 show that there was high significant difference in grain shape due to rice genotypes; Giza182 recorded the maximum grain shape (3.54). While the minimum value was found for Sakha 104 and Egyptian hybrid rice (2.14 and 2.33 , respectively).

Milling characters are shown in Table 2. Milling percentage is the measure of rough rice performance during milling process. It is the total quantity of head and broken grains recovered from unit of rough rice. Hulling involves removing the husk from the paddy with a minimum damage to the grain and separating the husk from the paddy to produce brown rice. Generally, hull percentage in difference varieties varies from $16-24 \%$. Rice variety Sakha 104 have the highest brown rice percentage $(81.48 \%)$, while Giza 182 recorded the lowest value $(78.04 \%)$. Whereas no significant difference between the varieties Sakha 104 and Egyptian hybrid1 in this respect. The process of removing the embryo and the outer bran layer from the brown rice is termed as whitening or milling. Results in Table 2 show that there was a significant difference among the tested genotypes in milling trait. Sakha 104 showed the highest milled rice percentage $(69.10 \%)$ comparing with the Giza 182 which produced the lowest value $(62.70 \%)$. The data also in Table 2 indicated that no significant differences between Sakha 104 and Egyptian hybrid1 in milled rice percentage. Also, it indicated that there was significant difference between Sakha 104 and Egyptian hybrid1 in head rice percentage. Sakha 104 surpassed significantly both two varieties under study (62.2\%), while Giza 182 had the lowest (51.70\%). Hulling, milling and head rice percentage were higher in Sakha 104 than the other verities under study. Head rice out-turns proportion of whole grain in milled rice. It depends on varietal characters and drying condition. 
Grain shape characters of some Egyptian rice genotypes

\begin{tabular}{llccc}
\hline \multicolumn{1}{c}{ Rice varieties } & \multicolumn{1}{c}{ Rice genotypes } & Grain length (mm) & Grain width (mm) & Grain shape \\
\hline Sakha 104 & Japonica (Shr.) & $5.50 \mathrm{~b}$ & $2.58 \mathrm{a}$ & $2.14 \mathrm{~b}$ \\
E. Hybrid 1 & Indica/Japo. (M) & $5.73 \mathrm{~b}$ & $2.46 \mathrm{a}$ & $2.33 \mathrm{~b}$ \\
Giza 182 & Indica (L) & $6.62 \mathrm{a}$ & $1.86 \mathrm{~b}$ & $3.54 \mathrm{a}$ \\
F-test & & $* *$ & $* *$ & $* *$ \\
\hline
\end{tabular}

Note: means designated by the same letter are not significantly, different at the $5 \%$ level by DMR test. Shr: short, M: medium, L: long.

Milling of some Egyptian rice genotypes

\begin{tabular}{llccc}
\hline \multicolumn{1}{c}{ Rice varieties } & \multicolumn{1}{c}{ Rice genotypes } & Hulling $\%$ & Milling $\%$ & Head Rice $\%$ \\
\hline Sakha 104 & Japonica (Shr.) & $81.48 \mathrm{a}$ & $69.10 \mathrm{a}$ & $62.20 \mathrm{a}$ \\
E. Hybrid 1 & Indica/Japo (M) & $79.05 \mathrm{ab}$ & $67.40 \mathrm{ab}$ & $60.60 \mathrm{a}$ \\
Giza 182 & Indica (L) & $78.04 \mathrm{~b}$ & $62.70 \mathrm{~b}$ & $51.70 \mathrm{~b}$ \\
F-test & & $*$ & $* *$ & $* *$ \\
\hline
\end{tabular}

Note: means designated by the same letter are not significantly, different at the 5\% level by DMR test. Shr: short, M: medium, L: long.

Data presented in Table 3 show that there were significant differences among rice genotypes for whitening. The highest value (54.80) was founded by Egyptian hybrid1. While, the lowest one was Sakha 104 (43.50). Also, data tabulated in the Table 3 reveal that cracks were highly significantly affected by rice genotypes. The highest cracks were recorded by Giza 182 Long grain (13.00), however the lowest was observed by Sakha 104 (short grain) and Egyptian hybrid1 (Medium grain). These two characters are mainly depending on the drying method of grains during ripening and methods of processing during milling.

Results pointed out that there were differences among the tested varieties in 1000-grain weight Sakha 104 and Egyptian hybrid1 were the heaviest 1000-grain weight (24.71 and 24.60 gm respectively). While the lightest one was recorded by Giza 182 which gave (22.80 gm). The studied rice genotypes could be ranked from heavier to lighter in 1000-grain weight as follows, Sakha 104 and Egyptian hybrid1 and Giza 182. It might be due to the big canopy or high leaf area which causes shading and decrease the light penetration consequently decrease photosynthesis and the filling of grains. Li et al. (1991) confirmed these results in his study and reported that high rates of fertilizer and fertile soils would have increased yields but grain filling was lower with increasing in rates.

Data presented in Table 4 show that the moisture content of milled rice grains for the three tested rice varieties ranged between $14.10 \%$ and $14.30 \%$., there was no significant differences in moisture content of milled rice grains varieties. Also, data revealed that there were insignificant effects in total carbohydrate of milled grains among rice genotypes. Milled rice grains of Sakha 104 had the lowest protein compared to the other two varieties (Egyptian hybrid1 and Giza 182) as given in Table 4. Whereas no significant difference was detected between Egyptian hybrid1 (Indica/Japonica) and Giza 182 (Indica). These results are in harmony with those reported by Shen-XinPing et al. (2003). It is known that many factors implicate the protein content of rice grain such as cultivars, climatic and environmental factor. In addition, the protein content of rice was affected by milling. This can be attributed to the fact that the content of protein in the paddy rice is much higher in the outer layer and decreases as we reach the inner layer (Sotelo et al., 1990). Total lipids content of milled rice grains ranged from $0.30 \%$ to $0.75 \%$. Table 4 it should be noted that Egyptian hybrid1 recorded the highest lipid while, milled grains of Giza 182 had the lowest one. Date given in Table 4 shows that the milled grains of rice varieties had different crude fibbers content. It should be noted that milled grains of Egyptian hybrid1 rice had the highest content of crude fibbers, while, the lowest content of crude fibbers was found in milled grains of Sakha 104. Table 4 represent that, Egyptian hybrid1 gave the highest ash content when compared to the two rice varieties under study followed by Sakha 104 and Giza 182 without significant difference between them (Sakha 104 and Giza182). There were significant differences among cultivars in respect to chemical composition due the genetic constitution of these genotypes.

Physical characters of some Egyptian rice genotypes

\begin{tabular}{llccc}
\hline \multicolumn{1}{c}{ Rice varieties } & \multicolumn{1}{c}{ Rice genotypes } & Whitening & Cracks & 1000-grain weight (gm) \\
\hline Sakha 104 & Japonica (Shr.) & $53.30 \mathrm{~b}$ & $5.00 \mathrm{~b}$ & $24.70 \mathrm{a}$ \\
E. Hybrid 1 & Indica/Japo (M) & $54.80 \mathrm{a}$ & $5.00 \mathrm{~b}$ & $24.60 \mathrm{a}$ \\
Giza 182 & Indica (L) & $43.50 \mathrm{c}$ & $13.00 \mathrm{a}$ & $22.80 \mathrm{~b}$ \\
F-test & & $* *$ & $* *$ & $*$
\end{tabular}

Note: means designated by the same letter are not significantly, different at the $5 \%$ level by DMR test. Shr: short, M: medium, L: long. 
Chemical compositions of some Egyptian rice genotypes (gm $\left.100 \mathrm{~g}^{-1}\right)$ on dry weight basis

\begin{tabular}{llcccccc}
\hline \multicolumn{1}{c}{ Rice varieties } & \multicolumn{1}{c}{ Rice Genotypes } & Moisture & Total Carbohydrates & Total protein & Total lipids & Crude fibbers & Ash \\
\hline Sakha 104 & Japonica (Shr.) & 14.30 & 91.30 & $6.40 \mathrm{~b}$ & $0.45 \mathrm{~b}$ & 0.66 & $0.50 \mathrm{~b}$ \\
E. Hybrid 1 & Indica/Japo (M) & 14.20 & 90.65 & $7.45 \mathrm{a}$ & $0.75 \mathrm{a}$ & 0.80 & $0.77 \mathrm{a}$ \\
Giza 182 & Indica (L) & 14.10 & 90.15 & $7.55 \mathrm{a}$ & $0.30 \mathrm{c}$ & 0.75 & $0.40 \mathrm{~b}$ \\
F-test & & $\mathrm{Ns}$ & $\mathrm{Ns}$ & $*$ & $* *$ & Ns & $* *$ \\
\hline
\end{tabular}

Note: means designated by the same letter are not significantly, different at the $5 \%$ level by DMR test. Shr: short, M: medium, L: long.

Some cooking and eating quality characters are affected greatly by different factors; others seem unaffected, depending on the degree of differences among genotypes. Data recorded in Table 5 show that Sakha 104 (Japonica type) had low amylose content $(18.20 \%)$, low gelatinization temperature $\left(6^{\circ} \mathrm{C}\right)$ and soft gel consistency (97.00). Mostly Indica and Japonica/ Indica rice genotypes had high amylose content and hard gel consistency, but the Egyptian rice varieties Giza 182 (Indica type) and E. hybrid (Japonica/Indica type) had soft gel consistency (83.00), (91.00) and low (19.70) and intermediate (21.00) amylose content respectively. All rice genotypes were low in gelatinization temperature. These results are due to that the Egyptian breeding program breed and select for these characters which accepted by the Egyptian consumers.

Data in Table 6 show cooking and processing characteristics for three different rice genotypes. The time required to peak viscosity in Japonica type is relatively less than the other two rice genotypes. Amylograms of Sakha 104 (Japonica type) show higher breakdown and much lower setback than the other two rice genotypes due to their lower amylose content. The Egyptian hybrid1 recorded the lowest peak viscosity, breakdown and setback due to their intermediate amylose content. Also, this may be attributed to their parents which they are Japonica/Indica hybrid although they are low in gelatinization temperature. The Indica and Japonica/Indica types are low in breakdown viscosity; but higher in cooked paste viscosity than japonica type. This in terms of solids loss during processing is relatively bold. The use of RVA peak viscosity, break down, consistency, setback and time required to peak viscosity is considered as good index for palatability evaluation for milled rice flours and starch.

Table 5 .

Some cooking quality characters of some Egyptian rice genotypes

\begin{tabular}{llccc}
\hline \multicolumn{1}{c}{ Rice varieties } & \multicolumn{1}{c}{ Rice Genotype } & Amylose $(\%)$ & Gel consistency $(\mathrm{mm})$ & Gelatinization temperature $\left(\mathrm{C}^{\circ}\right)$ \\
\hline Sakha 104 & Japonica (Shr.) & $18.20 \mathrm{c}$ & $97.00 \mathrm{a}$ & $6.00 \mathrm{~b}$ \\
E. Hybrid 1 & Indica/Japo (M) & $21.00 \mathrm{a}$ & $91.00 \mathrm{~b}$ & $6.00 \mathrm{~b}$ \\
Giza 182 & Indica (L) & $19.70 \mathrm{~b}$ & $83.00 \mathrm{c}$ & $7.00 \mathrm{c}$ \\
F-test & & $*$ & $* *$ & $*$ \\
\hline
\end{tabular}

Note: means designated by the same letter are not significantly, different at the $5 \%$ level by DMR test. Shr: short, M: medium, L: long.

Some cooking quality characters of some Egyptian rice genotypes

\begin{tabular}{llccccrrr}
\hline \multicolumn{1}{c}{ Rice varieties } & \multicolumn{1}{c}{ Rice Genotypes } & $\begin{array}{c}\text { Time to peak } \\
(\mathrm{min})\end{array}$ & Peak viscosity Break down & $\begin{array}{c}\text { Set back } \\
(50 \mathrm{c})\end{array}$ & $\begin{array}{c}\text { Consistency } \\
(50 \mathrm{c})\end{array}$ & $\begin{array}{c}\text { Set back } \\
(30 \mathrm{c})\end{array}$ & $\begin{array}{c}\text { Consistency } \\
(30)\end{array}$ \\
\hline Sakha 104 & Japonica (Shr.) & 6.38 & 288 & 72 & +30 & 60 & +13 & 110 \\
E. Hybrid 1 & Indica/Japo (M) & 6.43 & 215 & 45 & +75 & 120 & +103 & 150 \\
Giza 182 & Indica (L) & 6.40 & 225 & 67 & +87 & 155 & +130 & 190 \\
\hline
\end{tabular}

Note: Shr: short, M: medium, L: long.

Panel test were determined commonly by breakage. Expansion, whiteness and some other attributes of cooked milled rice are shown in Table 7. Also, eating quality of milled rice determined mainly by its amlylose/ amylopectin ratio of the starch. Data in Table 7 show the cooking properties of three rice genotypes at different water ratios. The Egyptian consumer prefers short and medium translucent milled rice than long grains of milled rice as clear in the table before cooking. Cooking time largely depends on the properties of the starch and water ratio. The japonica type Sakha 104 takes less time than the other two genotypes. Rice water ratio $(1: 2)$ needs less time for cooking than the other rice water ratios for the three different rice genotypes. Data presented in Table 7 show no big differences in odor and whiteness trait for all tested rice genotypes. The whiteness of milled rice after cooking was not affected at any water ratio, but it mainly depends on milling methods and ratios. Also, whiteness and odor depends on genetic factors of different rice genotypes. Water absorption and volume expansion during cooking are directly affected by amylose content while, Bhattacharya (2009) reported that water absorption and volume expansion are mainly the function of the surface area of milled rice. Giza 182 
recorded the best volume expansion among the three rice genotypes, even under the three rice/water ratio. Whiteness of milled rice after cooking was not affected at any water ratio. The whiteness of milled rice depends mainly on milling methods and milling ratios, as well as, genetic factors. Therefore, the breeders select the new lines for whiteness in the early generations.

Table 7.

Panel test of some Egyptian rice genotypes

\begin{tabular}{|c|c|c|c|c|c|c|c|c|}
\hline \multirow{2}{*}{ Rice variety } & \multirow{2}{*}{ Rice genotypes } & \multirow{2}{*}{ Rice/water ratio } & \multicolumn{3}{|c|}{ Before cooking } & \multirow{2}{*}{$\begin{array}{c}\text { Cooking time } \\
(\mathrm{min})\end{array}$} & \multirow{2}{*}{ Odor } & \multirow{2}{*}{ Expansion } \\
\hline & & & Grain length & Grain shape & Transe & & & \\
\hline \multirow[t]{3}{*}{ Sakha 104} & Japonica (Shr.) & $1: 1$ & 9 & 7 & 9 & 20 & 9 & 8 \\
\hline & & $1: 1.5$ & 9 & 7 & 9 & 18 & 9 & 7 \\
\hline & & $1: 2$ & 9 & 7 & 9 & 17 & 9 & 7 \\
\hline \multirow[t]{3}{*}{ E. Hybrid 1} & Indica/Japo (M) & $1: 1$ & 8 & 6 & 8 & 24 & 9 & 7 \\
\hline & & $1: 1.5$ & 8 & 6 & 8 & 22 & 9 & 8 \\
\hline & & $1: 2$ & 8 & 6 & 8 & 20 & 9 & 7 \\
\hline \multirow[t]{3}{*}{ Giza 182} & Indica (L) & $1: 1$ & 7 & 6 & 9 & 23 & 8 & 8 \\
\hline & & $1: 1.5$ & 7 & 6 & 9 & 23 & 8 & 9 \\
\hline & & $1: 2$ & 7 & 6 & 9 & 21 & 8 & 10 \\
\hline Rice variety & Rice genotypes & Rice/water ratio & Whiteness & Stickiness & Taste & Total score & & $\%$ \\
\hline \multirow[t]{3}{*}{ Sakha 104} & Japonica (Shr.) & $1: 1$ & 7 & 8 & 9 & 66 & & 82.5 \\
\hline & & $1: 1.5$ & 7 & 7 & 8 & 63 & & 78.8 \\
\hline & & $1: 2$ & 7 & 6 & 8 & 62 & & 77.5 \\
\hline \multirow[t]{3}{*}{ E. Hybrid 1} & Indica/Japo (M) & $1: 1$ & 7 & 8 & 5 & 58 & & 72.5 \\
\hline & & $1: 1.5$ & 7 & 7 & 8 & 61 & & 76.3 \\
\hline & & $1: 2$ & 7 & 7 & 7 & 59 & & 73.8 \\
\hline \multirow[t]{3}{*}{ Giza 182} & Indica (L) & $1: 1$ & 6 & 9 & 8 & 61 & & 76.3 \\
\hline & & $1: 1.5$ & 7 & 8 & 6 & 60 & & 75.0 \\
\hline & & $1: 2$ & 7 & 7 & 9 & 63 & & 78.8 \\
\hline
\end{tabular}

Note: Shr: short, M: medium, L: long.

Stickiness is one of the most important properties of rice eating quality for consumers. Water ratio and hardness of milled grains affect stickiness, but the amylose content is the most important factor in this respect. At $(1: 1)$ rice/water ratio for the three genotypes, stickiness was better than the other ratios as shown in Table 7. The Egyptian consumers prefer short grain rice varieties, although there are long grain varieties which have a good taste such as Giza 182 at (1:2) rice/water ratio.
Also the results recorded in Table 7 for Sakha 104 short grain variety with (1:1.) rice/ water ratio. Japonica type rice variety Sakha 104 recorded the best total score followed by Indica type Giza 182 while. Indica/Japonica type rice variety was the least one accepted by the referees as shown in Table 7. These results may be attributed to the differences in size of starch granules in the different three rice genotype.

\section{REFERENCES}

A.O.A.C. (1990): Association of Official Analytical Chemists Official methods of analysis. Washington. USA

Adair, C. R. (1952): The McGill miller method for determining the milled quality of small samples of rice. Rice J. 55. 2: 21-23.

Bhattacharya, K. R. (2009): Physicochemical basis of eating quality of rice. Cereal Chem. 86: 211-223.

Byun,Y.-Hong, S. I.-Mangalassary, S.-Bae, H. J.-Cooksey, K.-Park, H. J. (2010): The performance of organic and inorganic coated retort pouch materials on the shelf life of ready-to-eat rice products. LWT-Food Science and Technology. 43: 862-866.

Cagampang, G. B.-Perez, C. M.-Juliano, B. O. (1973): A gel consistency test for eating quality of rice .J. Sci. Food Agric. 24: 1589-1594.

Champagne, E. T.-Bett, K. L.-Vinyard, B. T.-McClung, A. M.BartonII, F. E.-Moldenhauer, K.-Linscombe, S.-McKenzie, K. (1999): Correlation between cooked rice texture and rapid visco analyser measurements. Journal of Cereal Chemistry. 76: 764-773.
Childs, N. (2006): Rice Situation and Outlook Yearbook. Economic Research different temperatures. Journal of Cereal Science 1171e85. Foods World. 54. 1: 18-28.

Derycke, V.-Veraverbeke, W. S.-Vandeputte, G. E.-De Man, W.Hoseney, R. C.-Delcour, J. A. (2005): Impact of protein on pasting and cooking properties of nonparbioled and parboiled rice. Cereal Chemistry. 82. 4: 468-474.

Duncan, D. B. (1955): Multiple range and multiple F. Test. Biometrics. 11: $1-24$.

El-Kady, A. (1999): Studies on the viscosity characters of rice flour. Al Azhar J. Agric. 29: 187-196.

Juliano, B. O. (1971): A simplified assay for milled rice amylose. Cereal Sci. Today. 16: 334-338.

Khush, G. S.-Paule, C. M.-Dela-Cruze, N. M. (1979): Rice grain quality evaluation and improvement at IRRI. Workshop on chemical aspects of rice grain quality. IRRI. Manila. Philippines. 
Li, M. M.-Xu, L.-Liu, C. W.-Cao, G. L.-He, H. H.-Han, L. Z. (2008): Progress of genetic research and QTL analysis for grain shape in rice. Journal of Agricultural Science and Technology. 10: 34-42.

Li, Z. L.-Wu, Y. L.-Xie, L. C.-Chew, Y. Q. (1991): A preliminary study of the production and dry matter distribution after heading in $\mathrm{N} 98 \mathrm{sX}$ Teqing (a two-line inter sub specific hybrid rice). Journal of South-China Agricultural, University. 12: 1-14.

Little, R.-Hilder, G.-Dawson, G. (1958): Differential effect of dilute alkali on 25 varieties of milled white rice. Cereal Chem. 35: $111-126$.

Lopez, A. C. B.-Pereira, A. J. G.-Junqueira, R. G. (2004): Flour mixture of rice flour, corn and cassava starch in the production of gluten-free white bread. Brazilian Archives of Biology and Techn. 47: 63-77.

Peryam, D.-Shapiro, R. (1955): Perception, preference Judgment-clubs to food quality. Ind. Quality Control. 11: 1-5.

Prasert, W.-Suwannaporn, P. (2009): Optimization of instant jasmine rice process and its physicochemical properties. Journal of Food Engineering. 95: 54-61.

Rani, S. M. R.-Bhattacharya, K. R. (1989): Rheology of rice flour pastes: effect of variety, concentration, and temperature and time of cooking. Journal of Texture Studies. 20: 127-137.

Shen, X. P.-Ding, T.-Zhang, H. C.-Huo, Z. Y.-Tao, X. J. (2003): Study on latitudinal change in amylose and protein content of several dominant rice varieties cultivated in Jiangsu Province Journal of Yangzhou University. Agric. and Life Sci. Edition. 24. $1: 37-40$.
Singh, V.-Okadome, H.-Toyoshima, H.-Isobe, S.-Ohtsubo, K. (2000): Thermal and physicochemical properties of rice grain flour and starch. Journal of Agric. and Food Chemistry. 48: 2639-2647.

Sodhi, N. S.-Singh, N.-Arora, M.-Sing, J. (2003): Changes in physicochemical, thermal, cooking and textural properties of rice during aging. J. of Food Processing and Preservation. 27: $387-400$.

Sotelo, A.-Sousa, V.-Montalvo, I.-Hernandez, M.-Aragon, L. H (1990): Chemical composition of different fraction of Mexican varieties of rice obtained in milling. Cereal Chem. 67. 2: 209-221.

Teo, C. H.-Abd, A.-Cheah, P. B.-Norziah, M. H.-Seow, C. C. (2000): On the roles of protein and starch in the aging of non-waxy rice flour. Food Chemistry. 69: 229-236.

Wang, J.-Gu, S.-Wan, X.-Gao, H.-Guo, T.-Su, N.-Lei, C.-Zhang, X.-Cheng, Z.-Guo, X.-Wang, J.-Jiang, L.-Zhai, H.-Wan, J (2008): Isolation and initial characterization of GW5, a major QTL associated with rice grain width and weight. Cell Res. 18: 1199-1209.

Xie, L.-Chen, N.-Duan, B.-Zhu, Z.-Liao, X. (2008): Impact of proteins on pasting and cooking properties of waxy and non-waxy rice. Journal of Cereal Science. 47: 372-379.

Yoon, D. B.-Kang, K. H.-Kim, H. J.-Ju, H. G.-Kwon, S. J.-Suh, J P.-Jeong, O. Y.-Ahn, S. N. (2006): Mapping quantitative trait loci for yield components and morphological traits in an advanced backcross population between Oryza grandiglumis and the $\mathrm{O}$. Sativa japonica cultivar Hwaseongbyeo. Theor. Appl. Genet. 112: $1052-1062$ 